\title{
Italien, Danmark og Den Anden Slesvigske Krig
}

af Bruno Berni

Oldforskeren Carl Christian Rafn (1795-1864) førte som sekretær og bestyrer af Det Kongelige Nordiske Oldskriftselskab en omfattende korrespondance med udenlandske lærde fra hele verden. Brevene findes i dag i Det Kongelige Biblioteks håndskriftsamling, og de belyser mangfoldige forhold. Blandt korrespondancen med italienske personligheder ${ }^{1}$ findes der således breve, som viser, hvordan krigen i 1864 blev anskuet fra dansk og italiensk side. Brevene antyder bl.a. planer om italienske frivilliges deltagelse i krigen på dansk side. Denne spændende episode fremdrages her af Dr. Bruno Berni.

Carl Christian Rafn beskæftigede sig i hele sit liv med Danmarks fortid, og både som historiker, antikvar og dansker var han meget følsom angående det tyske angreb. Hans stilling fremgår tydeligt af nogle breve, som han skrev til italienske videnskabsmænd få dage efter angrebet. Den 16. februar skriver Rafn til Bernardino Biondelli, ${ }^{2}$ at tyskerne vil føre »une guerre de l'injustice la plus criante $\aleph^{3}$ og hans bitterhed er forståelig, når man tænker på, at han $\mathrm{i}$ 1861 havde udgivet sine »Inscriptions runiques du Slesvig méridional«, som netop beviste den påstand, at det danske befolkningselement havde bosat sig i Slesvig før det tyske. Det er altså i forbindelse med sin historiske virksomhed, at Rafn skriver, at »monumenterne fra vores forhistorie viser på uigenkaldelig vis, at Slesvig i umindelige tider har været en dansk provins. Tyskerne som lever dér er kun indtrænglinge«. Samtidig udtrykker han en skarp kritik af nabofolket, idet han mener, at "Italien har vist haft lejlighed til at stifte bekendtskab med den virkelige karakter af dette folk, der er så begærligt efter erobringer på sine nabolandes bekostning « [her oversat fra fransk].

Netop erkendelsen af at Italien på det tidspunkt befandt sig over for lignende problemer og samme fjende, er udgangspunktet i de følgende breve. Arkæologen Giancarlo Conestabiles brev til Rafn, dateret 5. marts, udtrykker italienerens forståelse af de danske problemer, idet han skriver:

"De kan godt forestille Dem, at når en italiener skriger imod Østrig, er der gode grunde til at skrige så højt som muligt « [her oversat fra fransk]. Italiens politiske situation er nærmere beskrevet i Diego Bonghis brev, skrevet fra Neapel den 20. september, hvor det hedder:

"I vort kære Italien er enhver interesse optaget af politikken, og alle interesser og alle sjæle vender sig mod vor fremtid, som er presset af de to store 
problemer, Rom og Venedig [...]! Hvis Danmark er meget bekymret, har Italien ikke færre problemer« [her oversat fra italiensk].

Denne del af Rafns korrespondance er følelsesudbrud fra en videnskabsmand, der havde ofret hele sit liv på at studere sit lands historie. Men i samme læg findes der et brev, der indeholder mere konkrete historiske oplysninger. I april 1863 havde en oberst i den italienske hær, Ferdinand Dienheim-Chotomski, ${ }^{4}$ sendt et manuskript, "Album Paléographique de l'art chrétienne du moyen âge«, til Rafn. Denne svarede i samme måned, men korrespondancen mellem de to havde åbenbart ikke en fortsættelse, idet der i det omtalte læg ikke findes flere breve fra 1863. Chotomskis andet brev til Rafn er nemlig skrevet et år efter, den 6 . juni 1864 , og fortjener at blive gengivet i hele sin længde:

"Jeg glæder mig over at have mulighed for at erindre Deres Excellence om mig, og samtidig tager jeg mig ærbødigst den frihed at bede Dem om at underrette mig om den ansøgning, som den italienske general Lanti hertug af Montefeltro og General Dunn har sendt gennem Hans Majestæt kongen af Danmarks ambassadør i Turin, er nået frem. I ansøgningen tilbyder disse to generaler deres tjeneste til Deres Konge og ønsker at komme til Danmark med de italienske frivillige og kæmpe mod vores fælles fjende; da de på nuværende tidspunkt ikke har modtaget svar, og den danske ambassadør ikke er i Turin, ønsker de at få besked om deres tilbud er blevet positivt modtaget.

Vi er her i gang med at organisere en komité og vil (dersom vi får lov) komme Deres ulykkelige medborgere til hjælp, fordi de ruineres af preussernes og østrigernes opkrævning og plyndring. Forhenværende krigsminister grev Frapoli, hertug af Montefeltro, greve Cornaro, venetiansk adelsmand og $\mathrm{Hr}$. De Luca, folketingsmedlem har bifaldet projektet, og jeg er glad for at have taget initiativ til denne broderlige pligt, som den italienske nation har over for Deres heroiske land, og alle frimurerloger af vores skotske ritual og af andre vil bidrage til denne gode gerning. Mens vi venter, beder vi til Gud, om at De kan slå Deres ulykkelige lands angribere og plyndrere, et land, der er blevet forladt af Deres troløse allierede. Det mener alle dydige mennesker.

Jeg forsikrer Dem min respekt og agtelse ... etc.« [her oversat fra fransk]

I enhedsbevægelsens Italien var det Slesvigske spørgsmål altså ikke helt ukendt og heller ikke upåagtet. Man sagde, at Preussen-Østrig ville generobre fra Norden, hvad de havde tabt i Syden, og i februar 1864 troede man i Tyskland, at Italien ville angribe ved floden Mincio, som markerede grænsen mellem det $\mathrm{nu}$ italienske Lombardi og det endnu østrigske Venedig. De østrigske og preussiske tropper ville da blive fordelt på to fronter og dette ville gavne Danmark og samtidigt være i Italiens interesse. En svækkelse af de tyske 


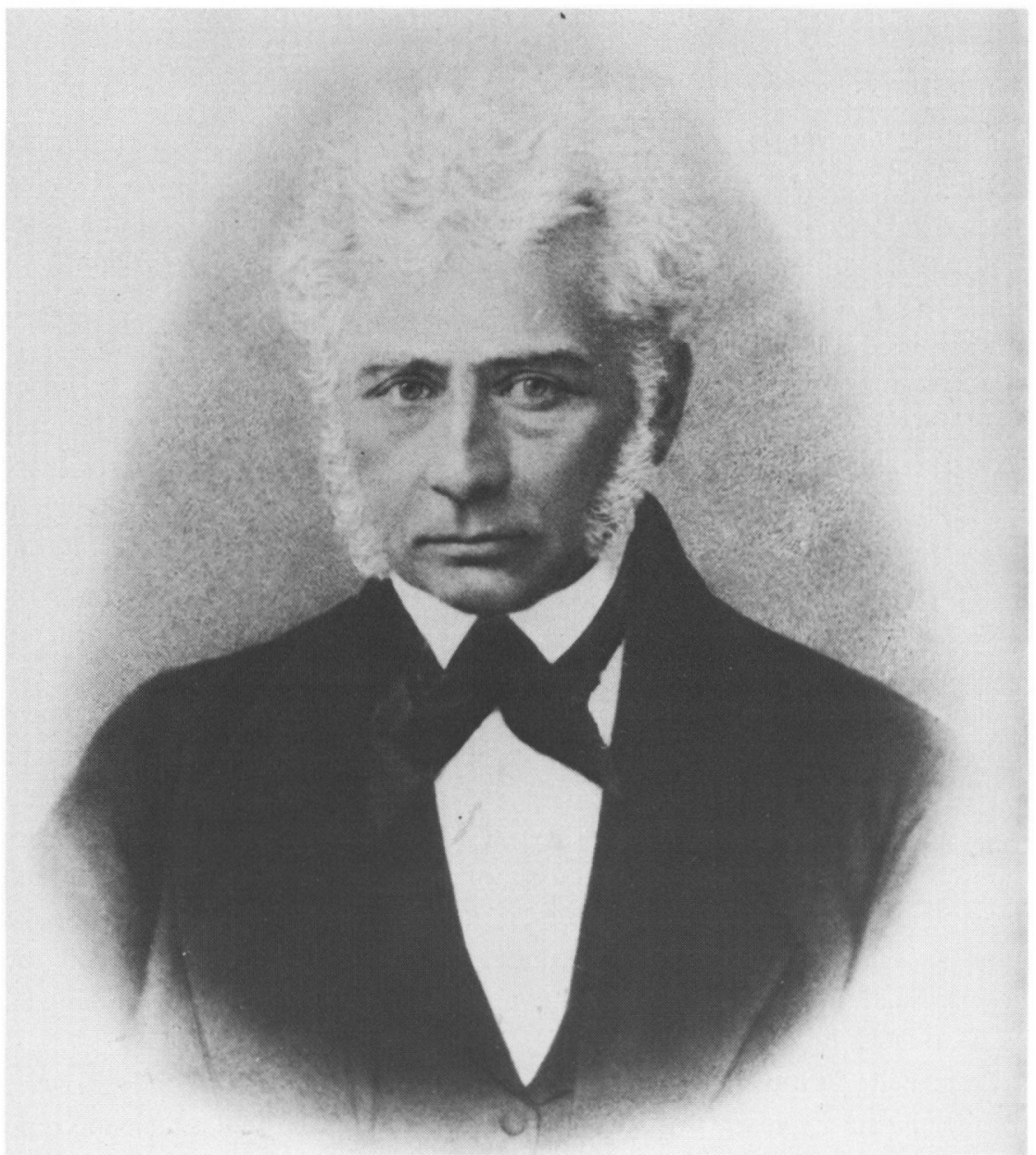

Carl Christian Rafn (1795-1864) viede sit liv til studiet af nordisk oldtid og oplysningsarbejdet herom. Han var med til at stifte Det $\mathrm{kgl}$. nordiske Oldskriftselskab og blev dets sekretar og egentlige leder. Undersogelser af stednavne og runeindskrifter fra Mellemslesvig overbeviste ham om, at hele Slesvig oprindelig havde dansk befolkning. Denne overbevisning forfagtede han besindigt over for tyske larde. som mente at landet tvartimod oprindelig var beboet af tyske stammer. Foto i Det kongelige Bibliotek.

tropper kunne altså komme begge lande til nytte. Det drejede sig kun om falske rygter, men den italienske statsminister Cavours opfattelse havde tidligere været den, at de danske problemer var af europæisk interesse, og at Sverige ikke kunne undgå at hjælpe Danmark. Cavour betragtede Preussen-Østrig som en fælles fjende, og derfor ville enhver mulighed for at volde dem besvær - fra skandinavisk eller italiensk side - være velset og måske støttet, hvis ikke 
militært, så politisk. Cavour var imidlertid død allerede i 1861, men meget var altså alligevel i gang i Italien med hensyn til erobringen af Venedig, hvilket skete i 1867.

Vore historiebøger omtaler imidlertid ikke nogen deltagelse af italienske frivillige i den anden slesvigske krig: hvordan tog sagen sig altså ud? Det har ikke været muligt $i$ danske arkiver at finde den originale ansøgning, som Chotomski omtaler i sit brev til Rafn, og noget tyder på, at en skriftlig officiel ansøgning aldrig er blevet forevist det danske gesandtskab i Turin. Men blandt Iver Holger Rosenkrantz' papirer i Rigsarkivet i København findes der et koncept til et brev fra ham til udenrigsministeren Monrad, hvor sagen er nærmere omtalt. ${ }^{5}$ Baron Rosenkrantz var blevet udnæunt til Chargé d'affaires ved det italienske hof den 21. juni 1863, og blev i Turin til 28. marts 1866, hvor han blev afskediget med ventepenge, og posten, der nu skulle flyttes til Florens, blev derimod inddraget. Rosenkrantz beretter i brevet - der i øvrigt er trykt $i$ hans "Efterladte Optegnelser ${ }^{6}$ - hvordan general Dunn den 12. april 1864 havde bragt ham et brev fra kammerherre Bille i London og samtidigt tilbudt at føre et korps på 6-10.000 frivillige til Danmark. General Dunns nøje forberedte plan var, at korpset skulle sejles til Danmark gennem Gibraltar-strædet om bord på engelske skibe, og dermed undgå de østrigske krydseres kontrol. Danmark skulle betale transportomkostninger og udrustning, og Dunns frivillige skulle i øvrigt have samme løn som de regulære danske soldater. Den danske ambassadør fortæller, hvordan han talte med den italienske indenrigsminister Peruzzi om sagen. Peruzzi og den engelske minister Elliot var, ifølge Rosenkrantz, underrettet om ekspeditionen, og Peruzzi sagde, at den italienske regering ville lukke øjnene for hvervningen, og ellers helst holde sig udenfor.

Dunn ville forestille Rosenkrantz for hertug af Montefeltro Della Rovere, som skulle stå i spidsen for det italienske korps, og ville selv omgående rejse til Danmark og organisere felttoget. Rosenkrantz var meget skeptisk over for de store omkostninger, og ikke mindst også på grund af Dunns tvivlsomme pålidelighed. En garanti for, at pengene ville blive brugt til at hjælpe Danmark mod Tyskland, og ikke - som Peruzzi antydede - til at finansiere en ny ekspedition i Italien, kunne Dunn ikke give. Men en kort politisk analyse af forholdene kan måske overbevise os om, at de italienske frivillige virkelig ville rejse til Danmark og kæmpe mod tyskerne. Netop dette ville på det tidspunkt hjælpe deres land. Det drejede sig altså om en slags politisk opportunisme, som Danmark kunne have fordel af. Blandt de italienske organisatorer, som Chotomski omtaler i sit brev til Rafn, var Ludovico Frapólli og Francesco De Luca. Den første havde været med i Garibaldis felttog på Sicilien og i Syditalien og havde tidligere rejst i Skandinavien, mens han studerede i Frank- 
rig. De Luca var siden 1861 parlamentsmedlem og blev senere vicepræsident. Begge var, sammen med de andre, der er nævnt i Chotomskis brev, medlemmer af den italienske frimurerorden og blev senere stormestre. Hele foretagendet var altså skabt $\mathrm{i}$ frimureriets tegn, og her bør man måske påpege, hvor meget frimureriet allerede tidligere havde virket sideløbende med Italiens enhedsbevægelse, både fra italiensk og udenlandsk side. 7 Giuseppe Garibaldi, Italiens berømte helt, blev støttet af en kreds af kendte frimurere og blev senere stormester 'honoris causa'. Og selv da Garibaldi erobrede Syditalien for Savoia-kongen Vittorio Emanuele, havde den italienske regering lukket øjnene og officielt holdt sig udenfor, selvfølgelig kun af politiske grunde over for resten af Europa.

Det italienske initiativ havde altså en alvorlig politisk hensigt, nemlig at yde Danmark støtte, og derved svække Preussen-Østrig og erobre Venedig. Denne taktiske idé var heller ikke ny for Ludovico Frapólli, der kun fả år forinden, sammen med György Klàpkà, var i gang med at organisere ungarske legioner med samme mål, nemlig at volde Østrig besvær på to fronter. Forsøget blev standset af Villafranca-freden, men blev senere taget op igen for at kunne virke sideløbende med Garibaldis felttog.

Hensigten med de to italienske generalers indsats var altså denne, og udenlandsk hjælp til Danmark i 1864-krigen var i øvrigt ikke kun en italiensk sag. Noget tyder på, at også andre var indstillede på at yde økonomisk hjælp til det skandinaviske land. I brevet omtaler Chotomski en »comité, der skulle komme de danske "Citoyens« til støtte, og i den del af Rafns korrespondance, der er udgivet af Benedict Grøndal, findes der et brev, dateret 4. marts 1864, fra Rafn til den engelske videnskabsmand Andrew James Symington. I brevet skriver danskeren, at han har læst $i$ Times ithat on the 20th ulto the Marquess of Clanricarde has called upon his countrymen for contributions to the danish soldiers", og videre at »at Lausanne in Switzerland has been issued a similar appeal, also at St. Petersburgh and many other places . $^{8}$

Klàpkà og Garibaldi indledte på en eller anden måde en form for samarbejde med henblik på at hjælpe hver sit land, men Danmark oplevede ikke det samme, og 1864-krigen blev en afgørende begivenhed i dansk historie. Der er som sagt ingen spor af italienske frivillige i Slesvig i vore historiebøger. Dunns og Montefeltros idé fik ingen følger, og der findes heller ikke noget svar fra Rafns side til Chotomski i det undersøgte læg, som ellers indeholder notater og koncepter til svar på de fleste breve. På det tidspunkt - midt i juni 1864 var Danmark i gang med Londonkonferencen, og forhandlingerne og våbenstilstanden var vist årsagen til, at man ikke anså udenlandsk hjælp for nødvendig. I lægget er der derimod et tegn på Rafns taknemmelighed over for italienernes tilbud. Det er et lille notat, hvor Rafn ordner forsendelsen af 
nogle af Oldskriftselskabets publikationer til Chotomski, og blandt disse de omtalte "Inscriptions runiques du Slesvig«. Forsendelsen, der skulle bære dedikationen "Pour quelques-uns des amis italiens du peuple danois $«, 9$ er dateret 17. juni, dvs. mens Londonkonferencen endnu var i gang og de europæiske stormagters forslag måske kunne afslutte krigen og give Danmark et håb.

Men den lille pakke havde knapt nået Italien, før den fuldkomne mangel på gensidig forståelse den 25. juni førte til Londonkonferencens og derved våbenstilstandens afbrydelse. Carl Christian Rafn døde $\mathrm{i}$ oktober samme år og nåede ikke at opleve fredstraktatens endelige afslutning.

\section{NOTER OG HENVISNINGER}

1. Ny Kgl. Saml. 1599iv.2.G folio.

2. Rafn havde været $i$ kontakt med Bernardino Biondelli siden 1838, og besøgte ham i Italien 1854.

3. „En højst uretfærdig krig«.

4. Chotomski, der var adelsmand af polsk oprindelse, havde været i Frankrig fra 1831, i Italien fra 1860. Han var antikvar, forfatter, kunsthistoriker og maler. I $1870 \mathrm{kom}$ han tilbage til Polen, hvor han dede i 1880 .

5. Rigsarkivet, Gesandtskabsarkiv (Papirer udtaget af Rosenkrantz' Arkiv).

6. Iver Holger Rosenkrantz, Nogle efterladte Optegnelser, Kjøbenhavn 1876.

7. Jfr.: Alessandro Luzio, La massoneria e il risorgimento italiano. Saggio storico-critico, 2 Bd., Bologna 1925.

8. Breve fra og til Carl Christian Rafn, med en biografi, udg. af Benedict Grøndal, Kjøbenhavn 1869 , s. 292-293.

9. "Til nogle italienske venner af det danske folk «. 